\begin{tabular}{lcl}
\hline \multicolumn{1}{c}{ A N N A L E S } \\
UNIVERSITATIS MARIAE CURIE-SKŁODOWSKA \\
LUBLIN - POLONIA \\
VOL. XXIII, 1 & SECTIO K & 2016 \\
\hline
\end{tabular}

Faculty of Political Science, Maria Curie-Skłodowska University in Lublin, Poland

\title{
Remarks about the Activity of Polish Communists in Soviet Russia 1918-19221
}

\begin{abstract}
There were a few thousand Polish communists in Soviet Russia in the first years after the October Revolution. The Polish Bureau of Agitation and Propaganda at the Russian Communist Party [Bolsheviks] - the so-called Polbiuro - was the most important agenda of Polish communists. This article concerns the position of Polish communists in the Soviet state, their role in the Polish-Bolshevik War, activity amongst the Polish population in post-revolutionary Russia as well as amongst Polish POWs. The article is an attempt to answer the question: how to evaluate the activity of Polish communists in the Soviet country in the first years after the revolution? Text is based mainly on archival material from the Russian State Archive of Socio-Political History (RGASPI) in Moscow and collections of a few Ukrainian and Polish archives (Donetsk, Warsaw).
\end{abstract}

Key words: communism, Soviet Russia, Polish-Bolshevik War, POWs, refugees, Polish Bureau

The Polish-Bolshevik War, known also as the War of 1920, in the Soviet and Russian historiography was called the Polish War. The war, being crucial for the Polish statehood, was extremely important in the history of the communist movement in Poland. In fact, the substantial part of Polish communists stayed in Russia during the years of 1918-1922; however, there are difficulties in determining the number of Poles in the territories under the Soviet rule before 1926.

1 The article is based on the paper "Not Only Dzerzhinsky. Polish Communists in Soviet Russia, 1918-1922", presented during the $47^{\text {th }}$ Annual Convention ASEEES, session: Revolutions, Refugees and Relations in War, 1918-1922, Philadelphia, PA, November 19-22, 2015. 
Polish communists in Russia were interested in showing the largest possible number of Poles. According to the so-called Polbiuro (Polish Bureau of the Russian Communist Party [Bolsheviks]), the most important Polish agenda in Soviet Russia, in August 1921 the number of Poles was not less than 3,000,000 of which the largest concentrations were in the former provinces of Belarus: Minsk, Gomel, Vitebsk, and Right Bank of Ukraine. On the Right Bank the most numerous Polish population was registered in Proskuriv, Berdychiv, Kamianets districts, and in the cities: Kiev, Odessa, Kharkov, Ekaterinoslav, Zhytomyr and Berdychiv. There were much less Poles on the Left Bank of Ukraine. However, the number of 3,000,000 seems to be exaggerated. According to the Soviet data from 1921, Polish nationality declared up to 395,000 persons residing in the territory of Russia, but we have no information on the subject from Ukraine and Belarus from this year. So, taking into consideration different sources (i.a. data of rescue and repatriation committees, Red Cross, etc.), we can estimate the number of Poles in the Soviet state shortly after the end of the Civil War at 1,200,000-1,500,000 people [Iwanow 1991: 30-33; Materski 2005: 131-132; Kupczak 1994: 38-39, 47; Nesterenko 2010: 87].

According to the First Census of Population of USSR, there were about 520,000 Poles in the Soviet Union in 1926. In fact, this figure is an underestimate. Actually, the local Belarusian and Ukrainian administration created a new, large category of Belarusians and Ukrainians of Roman-Catholic rite. As admitted by the director of the Regional Statistical Office in Minsk in 1926, the Census data was 'targeted consistent campaign of discrimination against the Polish population in Ukraine and Belarus'. Although since the end of the Civil War and the Polish-Bolshevik War assimilation progressed, the number of Poles was diminished by census enumerators in Soviet Ukraine and Belarus, and this concerned also the Orthodox Poles and mixed marriages. Some Poles due to fear of reprisals did not want to divulge true nationality, so the number of Poles in those republics has been underestimated, and most authors estimated that number at 782,000 (0.53\% of total number of population) [Masiarz 2004: 73-74]. It is difficult to specify the number of Polish children living in non-Polish orphanages in the Soviet Union, and the so-called bezprizorni (street children).

The majority of this population was Roman Catholic. Before the Russian revolutions and in the early years of the Soviet rule the social life of Poles concentrated mostly around the parishes and churches. The communists were aware of the anti-Soviet sentiment of the Catholic clergy in areas inhabited by the Polish population, and effectively tried to liquidate the Church structures and deprive of its normal functioning. The clergy were harassed, and, more frequently, forced to emigrate ${ }^{2}$.

The Polish population in the Soviet state was not homogenous. The largest group stated Poles from the Eastern Borderlands (in Polish Kresy), mainly farmers living

2 There are many publications (monographs and sources' editions) on the Polish minority and situation of the Catholic Church in the Soviet Union in the Polish historiography. There is selected literature at the end of the article. 
on the Right Bank of Ukraine and Belarus. Although many of them did not know the Polish language, they retained a strong sense of cultural identity and ethnicity. Among this group there were also people of Ukrainian, Belarusian and even Russian origin, who have adopted Catholicism. For majority of those groups, Poland was not a real historical existence, but rather a symbolic, longed-for homeland.

Another group formed emigration from the late $19^{\text {th }}$ and early $20^{\text {th }}$ centuries (among which there were the most skilled workers, craftsmen, intellectuals, engineers, former tsarist officials and the military). Apart from a small group of prisoners of war from the years of the First World War who chose or were forced to remain in Russia, there were also civil refugees and deportees, as well as people - mainly political prisoners - deported from the Polish lands before 1914 and their descendants. The least numerous were the communists, activists of the Polish and Russian communist parties, and people with the leftist views. Some of them emigrated from Poland during or shortly after the end of the Polish-Bolshevik War; the others were deported by the Polish authorities for ideological and political reasons (i.e. sabotage, espionage, communist propaganda and agitation). In this group were not only Poles but also people of Jewish origin, who considered themselves as Poles or declared Russian nationality [Budnitskii 2012: 47-50, 90-109; Pipes 1995: 260-261,312-326, 339-342; Schatz 1991: 31; Shternshis 2006: 82-105; Zieliński 2013: 94-103].

For Polish communists, the agitation and propaganda among Poles in the Soviet Union was very difficult. They had much less to offer than, for example, Jewish communists, who rightly pointed to the fact that anti-Semitism, at least officially, disappeared. Of course, the real anti-Semitism has not disappeared with taking power by the communists, and in subsequent years even deepened, but the Bolsheviks condemned the massacres and pogroms. There were Jews among the high ranks of new authorities, and especially indifferent religiously Jewish youth was relatively easy to seduce by visions of the new, fair state [Budnitskii 2012: 67; Slezkine 2004: 172-174; Zieliński 2013: 95-96].

Poles were the fourteenth nationality in Russia in terms of numbers, but taking into consideration the number of communists - members of the Russian and other communist parties - the Poles occupied the seventh position; so, the number of communists of Polish origin in relation to the number of total Polish population in the Soviet country was relatively large. According to the official Soviet data, 'Polish' party members in relation to the total number of Polish population were 3 times more numerous than showed similar indicators for the Russians, 7 times more numerous than the Belarusians and 10 times more numerous than the communist Ukrainians. In 1922, Polish communists in the Soviet country accounted approximately $1 \%$ of the total Polish population, while the proportion of communists among the general 
population of the state is $0.29 \%$. In terms of numbers it was the fourth group after Russians, Ukrainians and Jews [Kostiuszko 2005: 45; Kupczak 1994: 81-82] ${ }^{3}$. It is worth noting that the number of communist Poles in Russia outnumbered the number of communists in Poland (according to the Soviet data, the number of them was estimated at 15,000 to 18,000 , while in Poland in mid-1919 only 10,000). Although the majority of Poles in Russia was neutral to the collapse of the tsarist regime and the revolutions, nearly 8,000 of them took an active part in the Civil War [Butkiewicz, Ślisz 1987: 171; Cimek 2011: 29; Najdus 1971: 19-21; Świetlikowa 1968: 72-73].

What is more, Poles held significant positions at all levels and instances of the party, infamous Cheka (chrezvychaynaya komissiya, Emergency Committee) and military. Old, meritorious comrades, as Marchlewski, Dzerzhinsky, Radek belonged to the elite of the party and the government.

In the first years after the October Revolution, the activity of Polish communists in Soviet Russia, like communists of other nationalities and ethnicities, was under the directives from the Kremlin. It refers to all collective bodies that joined communists, namely Poles or those who were believed to be Poles. As I have mentioned, Polbiuro should be considered as the most important one in referring to a collective body. The Bureau was located in Moscow, and it fully represented the business of Polish communists in Russia. It was also the most important Polish body in the Bolshevik party, a party which was in fact above any Soviet state institutions. Moreover, some members of the Bureau were outstanding, distinguished revolutionaries, and highly-regarded figures in Polish as well as Russian and German working class movement. Among them were: Marchlewski, Dzerzhinsky, Kon, Unszlicht, Radek, etc ${ }^{4}$.

The Polish Bureau of the Communist Party was officially approved in 1919. It did not repeat the activity of Polish Section of the People's Commissariat of Nationalities, which had been active since 1917 (Polish section was the first out of sixteen ethnic sections of the Commissariat). Polbiuro was a 'child' of Lenin's ethnic policy, Bolshevik decision makers, and the theory of permanent revolution, which Soviet Russia was planning to carry into the West. Despite their own ambitions, in order to keep up with the general policy of Moscow, Polish communists could only become a part of Bolsheviks' plans and try to force through both their viewpoints and particularistic interests. Paradoxically, their biggest success was the fact that they convinced Lenin to conduct an armed confrontation with Poland [Davies 2006: 87, 184-185; Trembicka 1986/1987: 179-80]. However, that 'success' turned out to be their defeat at the same time, because the war result put an end to dreams about 'the

3 See also archival documents: RGASPI Russian National Archive of Social-Political History in Moscow (further RGASPI) Polish Bureau of Agitation and Propaganda at the Central Committee of the Russian Communist Party [Bolsheviks] (further F. 63) op. 1 d. 207, pp. 2-3.

4 Archive of Modern Acts in Warsaw (further AAN) Central Executive of the Polish Communist Workers' Party (further KPRP) 397/I-18 p. 18; RGASPI F. 63 op. 1 d. 26 p. 1-8; RGASPI F. 63 op. 1 d. 27 p. 1, 9, 16-20; RGASPI F. 63 op. 1 d. 29 p. 2; RGASPI F. 63 op. 1 d. 30 p. 6-7, 20-21; RGASPI F. 63 op. 1 d. 82 p. 34; RGASPI F. 63 op. 1 d. 207 p. 2-3, 7; RGASPI F. 63 op. 1 d. 209 p. 14. 
red flag waving in Warsaw' and the Polish Republic of Soviets, a component of the European or worldwide Federation of Soviet Russia.

However, after the October Revolution, the communist ideology was popular in the majority of states of East-Central Europe [Berend 2001: 65-69; Mendelsohn 1983: 2, 45; Rothschild 1998: 105, 142, 214-215, 295, 333-335, 372]. Let us look at the situation in Hungary.

Many Hungarian soldiers, coming from workers' and peasants' milieus, found themselves in Russian POW camps during the war. They returned to Hungary from Russia where their observations and experiences during 1917 and 1918 had converted them into communists. In fact, some of them had participated to considerable effect in the Russian Revolution and Civil War. At the conference in Moscow on November 4, 1918, they had resolved to found a Hungarian Communist Party, firstly as a Hungarian Group of the Russian Communist Party [Bolsheviks], and to send a few hundred of their agitators to Budapest. Its leader Béla Kun, an officer in the Austrian-Hungarian army, coming from the wealthy Jewish family in Budapest, returned to Hungary in November 1918, and started to deal with revolutionary movement. Despite the arresting of a few communist leaders, the party continued to prepare the revolution and to fulfill the resolution of the Communist International (Comintern). Kun and his comrades assumed that their revolution was a part of general European communist revolution and the beginning - as the first steps in this European revolution - of local upheavals in Germany and Austria. The 'Reds' came to power largely thanks its organized fighting force; they promised that Hungary would defend its territory without conscription, possibly with the help of the Soviet Red Army. The newly established Socialist Party of Hungary (communists and social-democrats) declared its intent to introduce the dictatorship of proletariat and to defend the national interests. The Budapest garrison offered its assistance, and a bloodless revolution introduced the dictatorship of the proletariat and established the Hungarian Council's Republic (March 21, 1919). However, the rule of communists turned out to be short-lived (133 days). On August 1, 1919, the Hungarian Council's Republic collapsed. A dozen years later the Hungary found itself in the German-Italian camp [Berend 2001: 124-129; Rothschild 1998: 142, 145-151].

Returning to Polish communists: Polbiuro was supposed to be a specialized institution dealing with Polish matters in the Soviet state. In the first years of its existence, the structure of Bureau was closely related to the war and military purposes. During the Polish-Bolshevik War of 1920 and its aftermath, the main part of Polbiuro activity was agitation and propaganda, and political work among returned expatriates, re-emigrants and prisoners of war. They were supposed to be won over and got in touch with communist parties that were active in the countries of their origin. Responsible sections of Polbiuro and other collegial bodies of Polish communists in Russia were supposed to preliminary train and recruit agents abroad and among the Poles in the Republic of Soviets [Nowak 2001: 546; Zieliński 2013: 325].

In July 1920, the Polish Bureau of the Russian Communist Party [Bolsheviks] was transformed into Provisional Polish Revolutionary Committee, the so-called 
Polrevkom. Theoretically, it was a new, temporary Polish government, but it seems to be more accurate to say that this was a Białystok branch (a headquarter of a new government was in this city) of Polish Bureau [Zieliński 2013: 18; Żenczykowski 1988: 43]. Polrevkom turned out to be an important and spectacular institution, but at the same time the short-term and failing episode in the activity of Polish Bureau. What is more, its short existence had a negative impact on the development of the communist movement in Poland. Far-reaching plans of Polish communists and hopes associated with the Polish-Bolshevik War for having the main role in a new Poland collapsed after the Battle of Warsaw.

However, the ceasefire and the Riga Treaty did not mean the end of the activity of Polish communists. The many Poles still lived in the Soviet state, and the communists had to take care of them and to persuade them to a new system. After the armistice, it became a main task of the Polish Bureau and its local branches.

The first local Polish bureau was established at the end of 1918 in Petrograd (it is estimated that $150-160,000$ of the total population of the city and its vicinity were Poles). The further branches were created depending on the number of Polish population and availability of staff. In March 1921, functioned 8 branches: Moscow, Petersburg, Kharkov, Rostov-on-Don, Baku, Tashkent, Novo-Nikolaevsk in Siberia and Minsk (Polish Bureau in Minsk operated under the auspices of the Central Committee of the Communist Party of Belarus). In May 1921, there were 58 Polish bureaus, in September -81 . In November of that year, there were 7 district bureaus and 44 provincial ones (including the territory of the RSFSR - 17, in Siberia - 8, in Donetsk Region - 4, in Ukraine - 11, and Belarus - 4). After repatriation and evacuation of refugees and POWs due to the decreasing number of the Polish population these numbers decreased. It was estimated that the number of Polish communists registered by the Polish bureaus reached 15-18,000, but some people still served in the Red Army, others after returning from the fronts did not want to register. There are no data from most villages in Belarus and almost the whole of Ukraine [Zieliński 2013: 76-89].

What did Polish communists in the Soviet state do? Some activities of this group should be interpreted as positivist 'work at the grass roots level'. What is meant here is a wide educational activity which was carried out despite the lack of financial support and personnel. The very important things were teaching children and fighting against illiteracy, including the illiteracy among POWs. Of course, ideological content was interwoven with education, although, it should not be presupposed that people learning how to read and write were doing it in order to transfer revolution into their country. The same can be stated about organization of re-evacuation, which was supervised and supported by Polish bureaus. From the technical side it was protected by Polish communists. Repeated interventions in dreadful welfare and living conditions, food supplies, corruption in camps and transit points of Polbiuro emissaries and pol-otdiels (Polish units) were sometimes successful. The anticipation of the return to their native country and the way home were more tolerable for many Polish refugees owing to the so-called Polish politrabotniki (political workers) 
who accompanied echelons [Leinwand 2008: 97-100; Stadnik 2004: 120-121] . Undoubtedly, what seems to be the most important from Bolshevik point of view, massive departures of refugees, returned expatriates and POWs gave chances to sneak agents and smuggle literature and propaganda materials for communists in Poland.

The activities connected with war, such as mobilization, the development of propaganda, organization of sabotage at the enemy's rear overlapped with the first stage of policy named korienisatsia. This term is meant, in this case, as policy of 'accustoming' Poles who lived and stayed in the Republic of Soviets with the communist ideology, trying to use their national aspirations rather than fighting with them. The main objectives of bureaus and sections were to integrate a particular national minority into a communist program, discredit 'bourgeois' scientific centres, eliminate centrifugal tendencies, widespread procommunist agitation and propaganda both in Russia and lands controlled by the Bolsheviks as well as neighboring countries. It must be admitted that it was extremely difficult to make attempts to respect Polish identity and at the same time to connect it with communism.

Although shortly after the Riga Treaty, in 1922 the massive re-evacuation and repatriation of Poles from the Soviet state were finished, many Poles lived in the 'new' Russia. The number of activities aimed at Polish population was substantial. Activists of Polbiuro were able to motivate some of those people, even though they appeared to be resistant to ideological load coming from the tribune or numerous brochures and newspapers. In fact, it is difficult to estimate the level of 'red infection' among the Poles in Soviet Russia: how to estimate the activity of Polbiuro and other Polish communist institutions towards Polish children, particularly war orphans? Re. the last question, on the one hand, the positive side to this activity was undoubtedly needed children's protection. The most important advantages of the existence of Polish schools and orphanages were, for example, meeting peers and teachers from the same village, having the same religious background or speaking the same mother tongue. The workers of Polish bureaus not only controlled social conditions, food supplies and the quality of education, but also they tried to transfer children to a Soviet-Polish orphanage if a village did not have one or it was to be closed down. We should remember that the Soviet state never managed to deal with the problem of bezprizornost (leaving children without any care or protection), which could be avoided by sending a child to a school or an orphanage. On the other hand, Polish schools and orphanages involved elimination of current educational system and repressions towards those teachers and Catholic priests that were not considered humble 6 . What is more, Polish communists tried to prevent children who were thought to have relatives in Poland from leaving the Republic of Soviets [Stadnik 2004: 131]. This fact was

5 Primary sources on the subject: RGASPI F. 63 op. 1 d. 45 p. 25. RGASPI F. 63 op. 1 d. 203 p. 19.

6 National Archive of the Donetsk Oblast in Donetsk (further GADO) Archive of the Communist Party of the Donetsk Oblast (further F. 1-2442) op. 1 d. 370 p. 24; op. 1 d. 62 p. 85; RGASPI F. 63 op. 1 d. 46 p. 35 . 
against the Treaty of Riga and also morally ambiguous, however, Polish communists really believed that keeping orphaned children in Soviet state would create a better future for them and save them from falling into 'destructive bourgeois and clerical influences'. Euphemistically speaking, seeking for those children's relatives in Poland in order to send them back to their native country as a part of repatriation was not too intense, because searches were often given up, newspaper advertisements were not sent to Polish press, and there were many administrative obstacles. It should be admitted that preventing as many Polish people as possible from leaving the Soviet state was in Polish communists' interests. It could justify further work of Polish communists, especially that they were convinced that they would be the best promoters of communism in the Polish nation owing to their origin, knowledge of Polish language and culture. The majority of those communists had never abandoned the hope for returning to Poland ${ }^{7}$. Paradoxically, belief in it helped Poland take back some artifacts of Polish culture and art monuments taken to Russia before 1918. At the Treaty of Riga the leading member of Polbiuro Leszczyński-Leński's argument concerning those monuments prevailed over all other statements. He said that those items were the property of Polish proletariat, and Polish proletariat was eventually going to take over the authority in Poland [Kostiuszko 2005: 101; Kumaniecki 1991: 167].

Taking care of Polish prisoners of war, despite the fact that the communists planned to recruit among them members of the Polish Communist Workers' Party and agents in Poland, was very important, too. Accessible materials are not enough to state that Polish communists were successful in this field. However, the fact that POWs could turn to Polish-speaking people with their problems was an unquestionable advantage. Their stay in prisoner-of-war camps was undoubtedly easier due to the presence of Polish workers and instructors [Zieliński 2013: 197-198].

It should be emphasized that among all repatriates to Poland, POWs were a particular category. In autumn 1918 in Russia, there were Polish soldiers who served during the First World War in German and Austrian formations, however, the problem of prisoners of war in all its complexity stood before the Bolsheviks and Polish communists in Russia after counteroffensive of the Red Army in 1920. The number of Polish POWs is difficult to estimate, and varies from 30 to 60,000 . Officials of the Polish section of Polish Repatriation Office talked about nearly 30,000 prisoners, but in the note of Polbiuro at the end of 1920 we found a number approximately 60,000 [Achmatowicz 1996: 186; Kostiuszko 2005: 52; Leinwand 2008: 95]. Probably these differences are due to the fact that they were soldiers of different fronts and years, as well as civilians and hostages.

The POWs stayed in dozens of camps, mainly in Soviet Russia, Ukraine and Belarus, however, some of them were sent to civilian camps. In general, the soldiers were separated from the officers, civilians and the Whites. Recommendations for the registration and categorization of prisoners were very detailed. In a report dated

\footnotetext{
7 RGASPI F. 63 op. 1 d. 47 p. 17.
} 
29 September 1920 we can read that: 'officers, priests, people from the privileged classes, intellectuals, people openly hostile to the Soviet state are to be spun off into a separate group and sent back farther separately from the other prisoners to specially designated camps'. These people belonged to the third category, and the political work among them did not promise any hope. For the first and second categories, potentially 'loyal', belonged respectively: workers, farm workers and small-holders, wealthier peasants and the 'petty-bourgeois elements'. Each category was, as far as possible, deposited in separate camps. This division concerned treatment of prisoners, too. One escaped from captivity Polish officer in his report for the delegation of the Red Cross stated that there are not officers' camps in Russia, and the officers often go to the prisons where their life 'is really slow agony' [Leinwand 2008: 98-99].

The best and the most experienced communist agitators were sent to POWs' camps. In the already quoted report, dated 29 September 1920 we can read that the political commissar's duties include: 'caring for the needs of prisoners, closer familiarization with them and supplying them with literature'. The role of political commissars, cooperating with local committees of the party, was big: they had a right to countersign all camp commandants' regulations, chiefs of concentration points and heads of echelons ${ }^{8}$. The central Polish Bureau even applied for replacing the camp commandants by Polish instructors-agitators, which would bring better results in the work of agitation and propaganda. It is possible that such requests were motivated by a desire to curb corruption that took place in many camps. Forms of work with prisoners included speeches, lectures, overviews of newspapers, reading fragments of revolutionary literature, etc. but also courses for illiterates. Prisoners daily or almost daily received, carefully chosen, Polish newspapers published in Russia or legal and illegal titles issued by the Polish communists in the country and relevant parts of 'bourgeois newspapers' from Poland. In addition to courses for illiterates, classes in arithmetic, economic history and the history of the labor movement were conducted. Meetings were arranged in the camps or the factory halls, warehouses, public facilities, clubs of Polish workers and youth, confiscated manors and churches?

In total, according to the Polish Bureau, there were approximately 24,000 prisoners in 34 camps on the territory of Central Russia and Siberia in 1921, and worked among them only 34 political instructors. However, there was established 11 schools for illiterates, 5 well-equipped libraries and 9 workers' clubs. The instructors organized 99 rallies, 151 lectures, 932 meetings. The 11 communists' circles were established (with 123 members and candidates for the party) and 6 schools for members of the party. Nearly 200 people joined the Red Army ${ }^{10}$. According to other sources, in 37 camps in Central Russia and Siberia in May 1921, stayed 32,000 POWs among whom worked 45 instructors. They established 29 schools for illiterates, 37 librar-

\footnotetext{
8 RGASPI F. 63 op. 1 d. 82 p. 26.

9 AAN KPRP 397/I-20 p. 81; RGASPI F. 63 op. 1 d. 203 p. 19.

10 RGASPI F. 63 op. 1 d. 25 pp. 31-37.
} 
ies, 15 clubs and reading rooms, 12 theaters and theatrical circles, 42 circles party, 9 party schools and 544 meetings were organized [Kostiuszko 2005: 16]. Despite the accuracy of these data, ideological ballast and motivation of Polish communists, the Polish Bureau and other agencies working among prisoners contributed to the reduction of illiteracy among soldiers, especially from the poor peasant families. It should be emphasized that this work due to the lack of staff, was not easy. A political work of the Polish communists in Russia over the Polish POWs brought little result. Actually, there is lack of information about signing up the communist party cards by Polish prisoners of the Polish-Bolshevik War.

The Bolshevik revolution did not spread throughout Central and Eastern Europe, therefore, the dreams of Polish communists failed. Although majority of them joined the fronts of the Russian Civil War, many were involved in the war with Poland. They believed that they are able to establish a 'new, better world' in Poland, but it does not change the fact that they acted in the interest of the Comintern (III Communist International), and they served the Soviet foreign policy. The same we can say about Béla Kun and his comrades [Rothschild 1998: 145-146]. Summing up, however, the presence of Polish communists (or - analogically - Hungarian, Slovak, Czech, Romanian, etc. communists) among the Polish POWs should be estimated positively. The presence of Poles and Polish-speaking people among the staff of the camps often facilitated the daily life of prisoners, like in the case of Polish repatriates and refugees waiting for return home.

As I have already mentioned, the Riga Treaty ending the Polish-Bolshevik War did not mean the end of the activity of Polish communists. In autumn 1922, Feliks Kon and Julian Marchlewski held a lecture at the Comintern conference in Moscow. They spoke out for creating Polish autonomous territorial and administrative units in Soviet Ukraine and Belarus close to the Polish border [Zieliński 2013: 325]. At that time, a base for the 'Polish experiment' was well prepared. A new phase in the history of the Polish minority in Soviet state begins.

The assessment of the activity of Polish communists in the Republic of Soviets in the years 1918-1922 must be ambivalent. Their attitude towards their country was indeed paranoid: despite all ideological reasons, to some extent their activity was a kind of treason. They fought shoulder to shoulder with the Red Army against Poland, their newly established country. Nevertheless, those passionate communists were really interested in making the Polish Soviet Republic, and underlined 'Polish' character of this Republic. Despite the ideological burdens, providing help to Polish children, POWs, refugees of the Great War and repatriates from all over the Soviet state deserves a positive assessment. 


\section{BIBLIOGRAPHY}

Primary sources:

AAN - Archive of Modern Acts in Warsaw

Collection: Central Executive of the Polish Communist Workers' Party

Number of folders: 397/I-18; 397/I-20.

GADO - National Archive of the Donetsk Oblast in Donetsk

Collection: Archive of the Communist Party of the Donetsk Oblast

Number of folders: F. 1-2442 op. 1 d. $62 ; 1$ d. 370; op. 1 d. 62.

RGASPI - Russian National Archive of Social-Political History in Moscow

Collection: Polish Bureau of Agitation and Propaganda at the Central Committee of the Russian Communist Party [Bolsheviks]

Number of folders: F. 63 op. 1 d. 25; op. 1 d. 26; op. 1 d. 27 ; op. 1 d. 29; op. 1 d. 30; op. 1 d. 45 ; op. 1 d. 46; op. 1 d. 47 ; op. 1 d. 82; op. 1 d. 203; op. 1 d. 207; op. 1 d. 209.

\section{LITERATURE}

Achmatowicz, A. 1996. Nowy snop światta na wojnę polsko-sowiecka 1919-1921. Nie publikowane dotąd dokumenty z archiwów rosyjskich, "Studia z Dziejów Rosji i Europy Środkowo-Wschodniej", vol. XXXI.

Berend I. T. 2001. Decades of Crisis. Central and Eastern Europe before World War II, University of California Press, Berkeley-Los Angeles-London.

Budnitskii, O. 2012. Russian Jews Between the Reds and the Whites 1917-1920, transl. T. J. Portice, University of Pennsylvania Press, Philadelphia.

Butkiewicz, T., Ślisz, A. 1987. Polscy żolnierze Wielkiego Października, Krajowa Agencja Wydawnicza, Warszawa.

Cimek, H. 2011. Mniejszości narodowe w ruchu rewolucyjnym w II Rzeczypospolitej, Wydawnictwo Uniwersytetu Rzeszowskiego, Rzeszów.

Davies, N. 2006. Orzet biaty, czerwona gwiazda. Wojna polsko-bolszewicka 1919-1920, przeł. A. Pawelec, Znak, Kraków.

Dzwonkowski, R. 1997. Kościól katolicki w ZSRR 1917-1939. Zarys historii, Towarzystwo Naukowe KUL, Lublin.

Dzwonkowski, R. 1998. Losy duchowieństwa katolickiego w ZSRR 1917-1939. Martyrologium, Towarzystwo Naukowe KUL, Lublin.

Grudzińska-Gross, I., Gross, J. T. (ed.) 2008. “W czterdziestym nas Matko na Sibir zesłali...”: Polska a Rosja 1939-1942, Znak, Kraków.

Iwanow, M. 1991. Pierwszy naród ukarany: Polacy w Związu Radzieckim 1921-1939, Państwowe Wydawnictwo Naukowe, Warszawa.

Kostiuszko, I. 2005. Polskoje biuro CK RKP[b] 1920-1921 gg., "Nauka", Moskwa.

Kumaniecki, J. 1991. Dwa oblicza dyplomacji radzieckiej. Rokowania w Mińsku i w Rydze, [in:] Wojna polsko-sowiecka 1920 roku. Przebieg walk i tło międzynarodowe, A. Koryn (ed.), IH PAN, Warszawa.

Kupczak, J. 1994. Polacy na Ukrainie w latach 1921-1939, Wydawnictwo Uniwersytetu Wrocławskiego, Wrocław.

Leinwand, A. 2008. Indoktrynacja jeńców polskich w bolszewickiej Rosji 1919-1921, "Studia z Dziejów Rosji i Europy Środkowo-Wschodniej”, vol. XXXVI.

Lizak, W. 1990. Rozstrzelana Polonia. Polacy w ZSRR 1917-1939, Prywatny Instytut Analiz Społecznych, Szczecin.

Madała, T. 1996. Polscy księża katoliccy w więzieniach i lagrach sowieckich od 1918 r., Wydawnictwo Retro, Lublin. 
Masiarz, W. 2004. ZSRR wobec Polaków w Rosji 1922-1991, [in:] Zwiazek Radziecki wobec krajów Europy Środkowej i Wschodniej 1920-1991, J. Diec, A. Tyszkiewicz (eds.), Wydawnictwo Dante, Kraków.

Materski, W. 2005. Na widecie. II Rzeczpospolita wobec Sowietów 1918-1943, ISP PAN - Oficyna Wydawnicza Rytm, Warszawa.

Mendelsohn, E. 1983. The Jews of East Central Europe between the World Wars, Indiana University Press, Bloomington.

Najdus, W. 1971. Lewica polska w Kraju Rad 1918-1920, Państwowe Wydawnictwo Naukowe, Warszawa.

Nesterenko, W. A. 2010. Polskoje nasielienije Prawobereżnoj Ukrainyw period ukraińskoj nacjonalno-demokraticzeskoj rewolucji (1917-1920 gg.), [in:] Poliaki w Rossii: epochi i sudby, Ch. Gralia, A. L. Pietrowskij, A. I. Selickij (eds.), Kubanskij Gosudarstwiennyj Uniwersitiet - Polskij Nacjonalno-Kulturnyj Centr „Jedinstwo”, Krasnodar.

Nowak, A. 2001. Polska i trzy Rosje. Studium polityki wschodniej Józefa Pitsudskiego (do kwietnia 1920 roku), Wydawnictwo Arcana - IH PAN, Kraków.

Pipes, R. 1995. A Concise History of the Russian Revolution, Knopf, New York.

Rothschild, J. 1998. East Central Europe between the Two World Wars, University of Washington Press, Seattle.

Samuś, P. 1983. Edward Próchniak, Książka i Wiedza, Warszawa.

Schatz, J. 1991. The Generation. The Rise and Fall of the Jewish Communists of Poland, University of California Press, Berkeley-Los Angeles-Oxford.

Shternshis, A. 2006. Soviet and Kosher. Jewish Popular Culture in the Soviet Union 1923-1939, Indiana University Press, Bloomington-Indianapolis.

Slezkine, Y. 2004. The Jewish Century, Princeton University Press, Princeton-Oxford.

Stadnik, K. 2004. The Repatriation of Polish Citizens from Soviet Ukraine to Poland in 1921-1922, [in:] Homelands. War, Population and Statehood in Eastern Europe and Russia, 1918-1924, P. Gatrell, N. Baron (eds.), Anthem Press, London.

Szczepański, J. 2000. Społeczeństwo Polski w walce z najazdem bolszewickim 1920 roku, Naczelna Dyrekcja Archiwów Państwowych - Wyższa Szkoła Humanistyczna, Warszawa-Pułtusk.

Świetlikowa, F. 1968. Komunistyczna Partia Robotnicza Polski 1918-1923, Książka i Wiedza, Warszawa.

Trembicka, K. 1986/1987. Komunistyczna Partia Robotnicza Polski wobec wojny polsko-radzieckiej w latach 1919-1920, "Annales UMCS" Sectio F, vol. XLI/XLII, 8.

Zieliński, K. 2013. O Polska Republikę Rad. Działalność polskich komunistów w Rosji Radzieckiej 19181922, Wydawnictwo UMCS, Lublin.

Żenczykowski, T. 1988. Dwa Komitety 1920 i 1944. Polska w planach Lenina i Stalina. Szkic historyczny, Wydawnictwo Społeczne KOS, Warszawa.

\section{BIOGRAPHY}

Konrad Zieliński, Professor of Social Science, Head of the Center for Ethnic Studies at the UMCS in Lublin (Faculty of Political Science). He deals with history and culture of the Jewish population in Poland and Russia, multiethnic relations, history of the Polish communist movement in USSR. Author of, among others, the following books: Stosunki polsko-żydowskie na ziemiach Królestwa Polskiego w czasie pierwszej wojny światowej (Lublin 2005), O Polska Republikę Rad. Działalność polskich komunistów w Rosji Radzieckiej 1918-1922 (Lublin 2013); co-author of the publication: The Lost World. Polish Jews. Photographs from 1918-1939 (Lublin-Warsaw 2015). E-mail: konrad.zielinski1@gazeta.pl 